\title{
Article \\ Can Knowledge of Genetic Distances, Genome Sizes and Chromosome Numbers Support Breeding Programs in Hardy Geraniums?
}

\author{
Mehrdad Akbarzadeh ${ }^{1,2, *}$, Katrijn Van Laere ${ }^{1}{ }^{(\mathbb{D}}$, Leen Leus ${ }^{1}$ (D), Jan De Riek ${ }^{1}$, Johan Van Huylenbroeck ${ }^{1}$ (D), \\ Stefaan P.O. Werbrouck ${ }^{2}$ and Emmy Dhooghe ${ }^{1}$ (D) \\ 1 Plant Sciences Unit, Flanders Research Institute for Agricultural, Fisheries and Food Research (ILVO), \\ Caritasstraat 39, 9090 Melle, Belgium; katrijn.vanlaere@ilvo.vlaanderen.be (K.V.L.); \\ leen.leus@ilvo.vlaanderen.be (L.L.); jan.deriek@ilvo.vlaanderen.be (J.D.R.); \\ johan.vanhuylenbroeck@ilvo.vlaanderen.be (J.V.H.); emmy.dhooghe@ilvo.vlaanderen.be (E.D.) \\ 2 Department Plants and Crops, Faculty of Bioscience Engineering, Ghent University, Coupure Links 653, \\ 9000 Ghent, Belgium; stefaan.werbrouck@ugent.be \\ * Correspondence: mehrdad.akbarzadeh@ugent.be
}

Citation: Akbarzadeh, M.; Van Laere K.; Leus, L.; De Riek, J.; Van Huylenbroeck, J.; Werbrouck, S.P.O.; Dhooghe, E. Can Knowledge of Genetic Distances, Genome Sizes and Chromosome Numbers Support Breeding Programs in Hardy Geraniums? Genes 2021, 12, 730. https://doi.org/10.3390/genes12050730

Academic Editors: Elwira Sliwinska, Monika Rewers and

Iwona Jedrzejczyk

Received: 30 March 2021

Accepted: 10 May 2021

Published: 13 May 2021

Publisher's Note: MDPI stays neutral with regard to jurisdictional claims in published maps and institutional affiliations.

Copyright: (c) 2021 by the authors. Licensee MDPI, Basel, Switzerland. This article is an open access article distributed under the terms and conditions of the Creative Commons Attribution (CC BY) license (https:// creativecommons.org/licenses/by/ $4.0 /)$.

\begin{abstract}
Breeding programs in ornamentals can be facilitated by integrating knowledge of phylogenetic relatedness of potential parents along with other genomic information. Using AFLP, genetic distances were determined for 59 Geranium genotypes, comprising 55 commercial cultivars of the three subgenera of a total collection of 61 Geranium genotypes. A subgroup of 45 genotypes, including intragroup and intergroup hybrids, were selected and further characterized for genome sizes and chromosome numbers. The variation in genome size ranged from $1.51 \pm 0.01 \mathrm{pg} / 2 \mathrm{C}$ to $12.94 \pm 0.07 \mathrm{pg} / 2 \mathrm{C}$. The chromosome numbers ranged from 26 to $108-110$ with some hybrids showing an aberrant number of chromosomes based on their parents' constitution. All chromosome numbers of Geranium are an even number, which presumes that unreduced gametes occur in some cross combinations. Overall, parental difference in genome size and chromosome number were not limiting for cross compatibility. Good crossing compatibility was correlated to a Jaccard similarity coefficient as parameter for parental relatedness of about 0.5 . Additionally, parent combinations with high differences in the DNA/chromosome value could not result in a successful cross. We expect that our results will enable breeding programs to overcome crossing barriers and support further breeding initiatives.
\end{abstract}

Keywords: 2C value; AFLP; chromosome counts; cross compatibility; hybridization; Geraniaceae; hybrids; Jaccard similarity coefficient

\section{Introduction}

The Geraniaceae comprises the genera Geranium (430 species), Pelargonium (280 species), Erodium (80 species) and Monsonia (40 species) resulting in a total number of more than 700 species [1-3]. Erodium and Geranium are phylogenetically closest related [4]. Hardy Geranium or cranesbill is a genus divided into three subgenera: Erodioidea with 22 species in four sections, Robertium with 30 species in eight sections, and Geranium with 380 species in at least ten sections [5]. This division into sections is still in flux [6]. Yeo divided the sections further in taxonomical groups based on a key with morphological characteristics [7] (Figure S1).

Geranium, a cosmopolitan genus, is adapted to well-watered soils and cool temperate regions [7]. The majority of the species originate in the temperate northern part of Eurasia. Most sections of subgenus Geranium consist of perennials from the east Mediterranean region but also extend to the western Himalayas with many species found in South America as well $[5,7,8]$. The other two subgenera contain annuals, biennials and summer-dormant 
tuberous species. The main distribution area of subgenus Erodioideae is Mediterranean, whereas subgenus Robertium extends from Macaronesia to the Far East.

The cultivation of Geranium started very recently, from the 1990s onwards, with the plants being used as hardy perennials [7]. Together with the cultivation of the plant, breeding and the first interspecific crosses were initiated. The first cranesbills on the market were G. macrorrhizum, G. sanguineum, G. himalayense, G. endressii and $G . \times$ oxonianum (G. endressii $\times$ G. versicolor). Later, others appeared, such as G. clarkei, G. $\times$ cantabrigiense (G. dalmaticum $\times$ G. macrorrhizum) and 'Ann Folkard' which was obtained by crossing G. procurrens and G. psilostemon. The best-selling Geranium ever is G. 'Rozanne' which is characterized by a long flowering period, large flowers and vigorous growth [9]. This cultivar is obtained as a spontaneous cross between G. himalayense and G. wallichianum and is mass-produced by micropropagation. 'Rozanne' has been selected as Plant of the Century at the Royal Horticultural Society (RHS) Chelsea Flower Show's 100th anniversary, received the Award of Garden Merit by RHS in 2006 and was honored as the Perennial Plant of the Year by the Perennial Plant Association (2008).

Most of the commercialized hardy geraniums are included in the subgenus Geranium, section Geranium. Until 2001, 165 different cross combinations had been released resulting from crosses between species in this section. In addition, 11, 14 and 13 different cross combinations between species of subgenus Robertium, within the subgenus Erodioidea, and between two subgenera (Geranium and Erodioidea), respectively, are on the market [7]. Although these different cross combinations have resulted in many commercial cultivars, not all cross combinations show equal success and many potentially interesting combinations are not possible at all. Specifically in the subgenus Geranium, G. endressii of the Endressii Group is compatible with the Sessiliflorum Group, while G. nodosum of this same Endressii Group is not compatible with any other species within this group [7] (Figure S1). Of the Sylvaticum Group, G. sylvaticum is crossable with G. endressii (Endressii Group) but only resulted in one hybrid with G. pratense. This combination, found in nature by Richard Nutt, could not be artificially reproduced [7]. Of this same Sylvaticum Group, G. psilostemon is the most successful genotype to cross with members of the Wallichianum Group and can be combined with G. endressii (Endressii Group), G. pratense (Pratense Group) and G. sanguineum (Sanguineum Group). G. sanguineum in turn can also be well combined with species of the Wallichianum Group. Members of the subgenus Robertium and members of the other two subgenera were found to be incompatible. All these examples clearly illustrate the limitations of the variation within Geranium. More knowledge about cross compatibility based on genome size, chromosome numbers and genetic relatedness would facilitate Geranium breeding.

Genome size is known to be an effective parameter for various plant characters like flower and shoot phenology. A positive correlation was seen between genome size and earliness of flowering as well as preferred environmental conditions in 219 geophytes [10,11]. Variation in genome size may also predict cross compatibility. For example, Cirsium species which are characterized by smaller genomes, tend to produce interspecific hybrids more frequently compared to those with larger genomes [12]. For the genus Geranium, genome sizes of some species from different taxonomic groups have been published, with variation between 1.44 and $8.36 \mathrm{pg} / 2 \mathrm{C}$ [13-16]. In addition, variation in chromosome numbers have been described [15-18]. For the subgenus Geranium, 11 chromosome numbers have been described [7]. The section Geranium has mostly 28 chromosomes $(2 n=2 x=28)$. For some species, however, the chromosome number is higher, such as G. macrorrhizum $(2 \mathrm{n}=46)$ and $G$. sanguineum $(2 \mathrm{n}=84)$. The chromosome number 28 is also found in all sections of the subgenus Erodioidea and in three sections of subgenus Robertium [3,7]. Phylogenetic taxonomic studies have been performed for Geranium for species originating from specific areas as North [19] and South America [5], Hawaii [20], Turkey [21] and New Zealand [6]. Phylogeny and historical biogeography in some genera of Geraniaceae also have been studied $[8,16,22]$. However, much knowledge is still lacking about genome sizes, chromosome 
numbers and genetic relationships, both for wild types as well as commercially interesting species and genotypes.

Using data on phylogenetic relatedness, chromosome numbers, ploidy level and genome sizes of parental species, predictions can be made concerning success of hybridization, as many studies show $[23,24]$. Hybridization between parents with unequal chromosome numbers is either less likely to occur [25] and/or results in other ploidy levels or sterile progeny [26]. For example, in Petunia two groups of chromosome numbers $(2 \mathrm{n}=2 \mathrm{x}=14$ and $2 \mathrm{n}=2 \mathrm{x}=18)$ exist and crosses between these two groups are not yet possible [25]. A study on Sarcococca showed higher cross efficiency between parents with equal ploidy level and genome size compared to parents with different genome size and ploidy level, while far genetic distances were less of a barrier to hybridization [27]. Instead, for Helleborus only parents with a threshold of 0.264 or higher of genetic proximity could give rise to interspecific hybrid offspring [28]. For Hydrangea, it has been shown that hybrids between species with large phylogenetic distance are sterile or non-vigorous [29-33]. A study on Buxus resulted in interspecific hybrids after crosses between two genetically non-related parents (B. sempervirens $(1.5 \mathrm{pg} / 2 \mathrm{C})$ and B. microphylla $(2.11-2.15 \mathrm{pg} / 2 \mathrm{C})$ ) [34]. In that study, AFLP analysis indicated that these hybrids were more closely related to B. microphylla, while their genome size was more similar to B. sempervirens. Many more examples are described in the literature.

In the present study, we examined the genome sizes, chromosome numbers and genetic relationships between different Geranium species and commercial cultivars including intra- and intergroup hybrids with the aim of supporting future breeding progams in Geranium. As our focus is on breeding we included mostly commercial cultivars. By combining our results with the available knowledge from the literature on cross compatibility in Geranium, we aim to provide thresholds for proximity values between parents for successful hybridizations. The knowledge obtained in this study about genetic relations, chromosome numbers, and genome sizes will elucidate the limits of variance in specific parameters and will contribute to successful combination of genotypes in breeding programs for Geranium.

\section{Materials and Methods}

\subsection{Plant Material}

A Geranium plant collection of 61 genotypes that covers all three subgenera of Geranium (Geranium, Erodioidea and Robertium) and includes 12 different taxonomical groups (with one genotype G. 'Bob's Blunder' G03, with unknown parents) has been created at ILVO, Melle, Belgium (Tables 1 and 2). The group division of Yeo [7] was used (Figure S1). We included 11 intragroup hybrids and 14 intergroup hybrids in this collection (Table 2). The plants were chosen based on whether they had morphological characteristics deemed valuable for commercial hardy geraniums. Plants were grown in 2L pots (peat-based substrate (Saniflor NPK 12:14:24, EC $45 \mathrm{mS} / \mathrm{m}$ )) except for G. cinereum which was potted in stone mixture (Kift) and were kept under greenhouse conditions (natural conditions, set-point for ventilation $10^{\circ} \mathrm{C}$ ). The identification of the specimens in the collection was confirmed by a collector of hardy geraniums (Dirk Gunst, Belgium).

\subsection{AFLP}

DNA extraction was performed from $20 \mathrm{mg}$ lyophilized young leaf material according to a modified CTAB DNA isolation protocol of Doyle and Doyle [35] for 59 genotypes of our Geranium collection. AFLP [36] was performed as in De Riek et al. [37] using the commercially available kit from Perkin-Elmer Biosystems for fluorescent fragment detection [36-38]. The primer combinations were: EcoRI-AAC/MseI-CAG, EcoRI-AAG/MseICAG, EcoRI-ACA/MseI-CTT and EcoRI-AGG/MseI-CAG. Band scoring and statistical analyses was based on De Riek et al. [37]. After calculating of a proximity matrix using the Jaccard similarity coefficient, both clustering and Principal Coordinate Analysis (PCoA) were applied. 
Table 1. List of all commercial cultivars and wild genotypes per subgenus included in the collection of Geranium and their genome sizes (Gen. size (pg/2C)), chromosome numbers (Chrom. numb.) and DNA/chromosome (DNA/chrom. (pg/chromosome)) (divided into taxonomical groups according to Yeo [7]). The plant species used as internal standard is mentioned with the genome size (Zea mays (M), Pisum sativum (P) and Glycine max (S)). The abbreviations for the taxonomical groups are the following: $\mathrm{C}=$ Cinereum, $\mathrm{E}=$ Endressii, $\mathrm{M}=$ Maculatum, $\mathrm{MA}=$ Macrorrhizum, $\mathrm{P}=\mathrm{Phaeum}, \mathrm{PA}=\mathrm{Palustre}$, $\mathrm{PL}=$ Platypetalum, $\mathrm{PR}=$ Pratense, $\mathrm{SA}=$ Sanguineum, $\mathrm{SE}=$ Sessiliflorum, $\mathrm{SY}=$ Sylvaticum, $\mathrm{W}=$ Wallichianum .

\begin{tabular}{|c|c|c|c|c|c|}
\hline Genotype Number & Name & Taxonomical Group & Gen. Size (pg/2C) & Chrom. Numb. & DNA/Chrom. \\
\hline \multicolumn{6}{|l|}{ Subgenus Geranium } \\
\hline G03 & G. 'Bob's Blunder' y & Unknown & $5.31(S)$ & $2 n=38$ & 0.140 \\
\hline G09 & G. pratense 'Galactic' y & PR & $4.92(\mathrm{P})$ & $2 n=28$ & 0.175 \\
\hline $\mathrm{G} 12^{\mathrm{z}}$ & G. psilostemon 'Matu Vu' y & SY & $\begin{array}{c}4.92(1) \\
-\end{array}$ & $\begin{array}{c}211-20 \\
-\end{array}$ & - \\
\hline G19 & G. nodosum 'Silverwood' y & $\mathrm{E}$ & $3.38(\mathrm{M})$ & $2 n=28$ & 0.121 \\
\hline $\mathrm{G} 20^{\mathrm{z}}$ & G. pratense 'Summer Skies' x & PR & - & - & - \\
\hline G21 & G. wallichianum 'Sylvia's Surprise'y & $\mathrm{W}$ & $6.78(\mathrm{P})$ & $2 n=28$ & 0.242 \\
\hline G35 & G. endressii x & $\mathrm{E}$ & $3.12(\mathrm{M})$ & $2 n=26$ & 0.120 \\
\hline G37 & G. endressii 'Trevor Bath' x & $\mathrm{E}$ & $3.48(\mathrm{M})$ & $2 n=28$ & 0.124 \\
\hline G38 & G. himalayense 'Baby Blue' $\mathrm{x}$ & PR & $7.31(\mathrm{M})$ & $2 n=56$ & 0.130 \\
\hline G39 & G. himalayense 'Derrick Cook' $\mathrm{x}$ & PR & $7.49(\mathrm{M})$ & $2 n=56$ & 0.134 \\
\hline G45 & G. maculatum 'Album'x & $\mathrm{M}$ & $7.64(\mathrm{M})$ & $2 n=52$ & 0.147 \\
\hline G46 & G. maculatum 'Elizabeth Ann' x & $\mathrm{M}$ & $7.63(\mathrm{M})$ & $2 n=52$ & 0.147 \\
\hline G57 & G. pratense 'Algera Double' y & PR & $5.08(\mathrm{P})$ & $2 n=28$ & 0.185 \\
\hline $\mathrm{G} 58^{\mathrm{z}}$ & G. pratense 'New Dimension' w & PR & $\begin{array}{c}0.00(1) \\
-\end{array}$ & - & - \\
\hline $\mathrm{G} 59^{\mathrm{z}}$ & G. pratense 'Cloud Nine' w & PR & - & - & - \\
\hline $\mathrm{G} 60^{\mathrm{z}}$ & G. pratense 'Plenum Album' w & PR & - & - & - \\
\hline G61 & G. pratense 'Purple Ghost' w & PR & $5.08(\mathrm{P})$ & $2 n=28$ & 0.181 \\
\hline G62 & G. psilostemon $\mathrm{y}$ & SY & $5.18(P)$ & $2 n=42$ & 0.123 \\
\hline G64 & G. renardii $\mathrm{x}$ & PL & $2.35(\mathrm{M})$ & $2 n=28$ & 0.084 \\
\hline $\mathrm{G} 68^{\mathrm{z}}$ & G. sanguineum 'Pink Pouffe' $\mathrm{x}$ & SA & - & - & - \\
\hline G69 & G. sanguineum 'Album' x & SA & $8.78(\mathrm{M})$ & $2 n=84$ & 0.104 \\
\hline G71 & G. sylvaticum 'Album' w & SY & $4.76(\mathrm{P})$ & $2 n=28$ & 0.170 \\
\hline G73 & G. versicolor $\mathrm{w}$ & $\mathrm{E}$ & $3.53(\mathrm{M})$ & $2 n=26 / 28$ & $0.126-0.136$ \\
\hline G76 & G. wallichianum 'Havana Blue' $\mathrm{x}$ & $\mathrm{W}$ & $6.86(P)$ & $2 n=28$ & 0.245 \\
\hline G77 & G. wlassovianum ${ }^{\mathrm{x}}$ & PA & $11.50(\mathrm{P})$ & $2 n=56$ & 0.205 \\
\hline G81 & G. clarkei 'Kashmir Purple' x & PR & $4.70(P)$ & $2 n=28$ & 0.168 \\
\hline \multicolumn{6}{|l|}{ Subgenus Erodioidea } \\
\hline G10 & G. cinereum 'Jolly Jewel Red' x & C & $6.39(\mathrm{P})$ & - & - \\
\hline G30 & G. cinereum 'Laurence Flatman' w & $\mathrm{C}$ & $6.06(P)$ & $2 n=28$ & 0.217 \\
\hline $\mathrm{G} 53^{\mathrm{z}}$ & G. phaeum 'Album'x & $\mathrm{P}$ & - & - & - \\
\hline G54 & G. phaeum 'Angelina' x & $\mathrm{P}$ & $3.52(\mathrm{M})$ & $2 n=28$ & 0.126 \\
\hline $\mathrm{G} 55^{\mathrm{z}}$ & G. phaeum 'Blauwvoet' $\mathrm{x}$ & $\mathrm{P}$ & 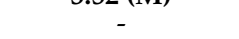 & - & - \\
\hline $\mathrm{G} 56^{\mathrm{z}}$ & G. phaeum 'Klepper' x & $\mathrm{P}$ & - & - & - \\
\hline \multicolumn{6}{|l|}{ Subgenus Robertium } \\
\hline G42 & G. macrorrhizum 'Czakor' y & MA & $1.60(\mathrm{M})$ & $2 n=46$ & 0.035 \\
\hline $\mathrm{G} 43^{\mathrm{z}}$ & G. macrorrhizum 'Spessart' w & MA & - & - & - \\
\hline G44 & G. macrorrhizum 'White Ness' ${ }^{x}$ & MA & $2.96(\mathrm{M})$ & $2 n=92$ & 0.032 \\
\hline G82 & G. dalmaticum ${ }^{\mathrm{x}}$ & MA & $1.56(S)$ & - & - \\
\hline
\end{tabular}

${ }^{\mathrm{z}}$ These genotypes are not further characterized for genome sizes and chromosome numbers. Source of plant material with ${ }^{\mathrm{y}}$ Denis-Plants,

x Jan Spruyt_-Van der Jeugd, ${ }^{\mathrm{w}}$ Kwekerij Jan Neelen. 


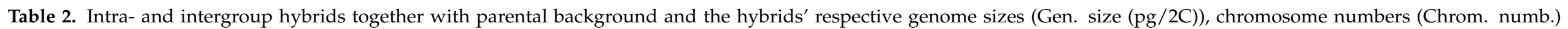

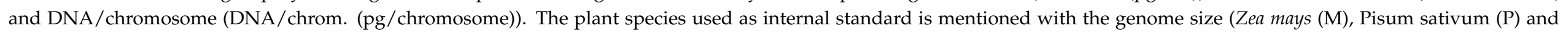

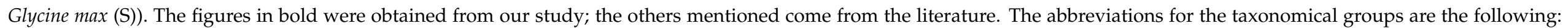

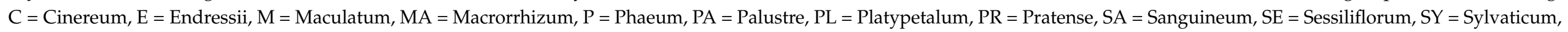
$\mathrm{W}=$ Wallichianum.

\begin{tabular}{|c|c|c|c|c|c|c|c|c|c|c|c|c|}
\hline \multicolumn{13}{|c|}{ Subgenus Geranium-Ntragroup Crosses } \\
\hline $\begin{array}{l}\text { Genotype } \\
\text { Number }\end{array}$ & Name & $\begin{array}{c}\text { Gen. Size } \\
(\mathrm{pg} / 2 \mathrm{C})\end{array}$ & $\begin{array}{c}\text { Chrom. Numb. } \\
(2 n=)\end{array}$ & DNA/Chrom. & Parent 1 & $\begin{array}{c}\text { Gen. Size } \\
(\mathrm{pg} / 2 \mathrm{C})\end{array}$ & $\begin{array}{l}\text { Chrom. Numb. } \\
(2 n=)\end{array}$ & DNA/Chrom. & Parent 2 & $\begin{array}{c}\text { Gen. Size } \\
(\mathrm{pg} / 2 \mathrm{C})\end{array}$ & $\begin{array}{l}\text { Chrom. Numb. } \\
(2 n=)\end{array}$ & DNA/Chrom. \\
\hline G04 & $\begin{array}{l}\text { G. 'Brookside' w } \\
\text { 'B }\end{array}$ & $4.54(\mathrm{M})$ & 28 & 0.162 & G. pratense (PR) & $4.92-5.08,4.83$ & $28,28,56$ & $0.175-0.185$ & G. clarkei (PR) & 4.70 & 28 & 0.168 \\
\hline G06 & $\begin{array}{l}\text { G. 'Chantilly' w } \\
\text { G'Orion'w }\end{array}$ & 2.31 (M) & 28 & 0.082 & G. gracile (PL) & - & - & -- & G. renardii $(\mathrm{PL})$ & 2.35 & 28 & $\begin{array}{l}0.084 \\
0130-0134\end{array}$ \\
\hline G17 & $\begin{array}{l}\text { G. 'Orion'w } \\
\text { G. 'Salome' w }\end{array}$ & $\begin{array}{l}6.93(\mathrm{P}) \\
9.25(\mathrm{~S})\end{array}$ & & & $\begin{array}{l}\text { G. Brookside (PR) } \\
\text { G. lambertii (W) }\end{array}$ & 4.54 & 28 & & $\begin{array}{l}\text { G. himalayense }(\mathrm{PR}) \\
\text { G. procurrens }(\mathrm{W})\end{array}$ & & 56 & \\
\hline $\mathrm{G} 23^{\mathrm{z}}$ & G. 'Terre Franche'v & - & - & - & $\begin{array}{l}\text { G.'Philippe Vapelle' } \\
\text { (PL) }\end{array}$ & - & - & - & G. platypetalum (PL) & - & - & - \\
\hline G49 & $\begin{array}{l}\text { G. } \times \text { oxonianum } \\
\text { 'Katherine Adele' w }\end{array}$ & $3.73(\mathrm{M})$ & 26 & 0.143 & G. versicolor (E) & 3.53 & $26 / 28$ & $0.126-0.136$ & G. endressii $(\mathrm{E})$ & 3.12-3.48, 3.13 & $26 / 28,26,28$ & $0.120-0.124$ \\
\hline G50 & $\begin{array}{l}\text { G. } \times \text { oxonianum } \\
\text { 'Southcombe Double' w }\end{array}$ & $3.22(\mathrm{P})$ & 26 & 0.124 & G. versicolor $(\mathrm{E})$ & 3.53 & $26 / 28$ & $0.126-0.136$ & G. endressii (E) & $3.12-3.48,3.13$ & $26 / 28,26,28$ & $0.120-0.124$ \\
\hline \multicolumn{13}{|c|}{ Subgenus Geranium-Intergroup Crosses } \\
\hline $\begin{array}{l}\text { Genotype } \\
\text { Number }\end{array}$ & Name & $\begin{array}{c}\text { Gen. Size } \\
(\mathrm{pg} / 2 \mathrm{C})\end{array}$ & $\begin{array}{c}\text { Chrom. numb. } \\
(2 \mathrm{n}=)\end{array}$ & DNA/chrom. & Parent 1 & $\begin{array}{c}\text { Gen. Size } \\
(\mathrm{pg} / 2 \mathrm{C})\end{array}$ & $\begin{array}{l}\text { Chrom. numb. } \\
(2 n=)\end{array}$ & DNA/chrom. & Parent 2 & $\begin{array}{c}\text { Gen. Size } \\
(\mathrm{pg} / 2 \mathrm{C})\end{array}$ & $\begin{array}{l}\text { Chrom. numb. } \\
(2 n=)\end{array}$ & DNA/chrom. \\
\hline G01 & G. 'Anne Thomson'x & $8.27(\mathrm{M})$ & 58 & 0.143 & G. procurrens $(\mathrm{W})$ & & - & - & G. psilostemon (SY) & 5.18 & 42 & 0.123 \\
\hline G02 & G. 'Azure Rush'x & $8.90(\mathrm{M})$ & 42 & 0.212 & G. wallichianum (W) & $6.78-6.86$ & $28,26,28,56$ & $0.242-0.245$ & G. 'Rozanne & 9.25 & 42 & 0.220 \\
\hline G05 & G. 'Catherine & $6.95(\mathrm{M})$ & 54 & 0.129 & G. psilostemon (SY) & 5.18 & 42 & 0.123 & G. $\times$ oxonianum $(\mathrm{E})$ & $3.22-3.73$ or - & 26 or - & $0.124-0.143$ \\
\hline G07 & G. 'Dragon Heart' w & $12.57(P)$ & 88 & 0.143 & G. psilostemon (SY) & 5.18 & 42 & 0.123 & G. procurrens $(\mathrm{W})$ & - & - & \\
\hline $\mathrm{G}^{2} 8^{\mathrm{z}}$ & G. 'Dusky Crûg'v & - & - & - & $\begin{array}{c}\text { G. } \times \text { antipodeum }{ }^{y^{\prime}} \\
\text { (SE) }\end{array}$ & - & - & 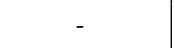 & G. $\times$ oxonianum $(\mathrm{E})$ & - & - & $0.124-0.143$ \\
\hline G11 z & G. 'Lilac Ice' ${ }^{x}$ & - & - & - & G. wallichianum (W) & $6.78-6.86$ & $28,26,28,56$ & $0.242-0.245$ & $\begin{array}{l}\text { G. 'Rozanne' } \\
(\mathrm{W} \times \mathrm{PR})\end{array}$ & 9.25 & 42 & 0.220 \\
\hline G13 & G. $\times$ riversleaianum & $4.31(\mathrm{p})$ & 38 & 0.113 & G. endressii (E) & 3.12-3.48, 3.13 & $26 / 28,26,28$ & $0.120-0.124$ & G. traversii (SE) & - & $28,52,54,56$ & - \\
\hline G15 & G. 'Patricia' & $5.10(\mathrm{P})$ & & & G. endressii (E) & $3.12-3.48,3.13$ & $26 / 28,26,28$ & $0.120-0.124$ & G. psiloster & 5.18 & 42 & 0.123 \\
\hline G16 & G. 'Rozanne' $x$ & 9.25 (M) & 42 & 0.220 & G. wallichianum (W) & $6.78-6.86$ & $28,26,28,56$ & $0.242-0.245$ & G. himalay & $7.31-7.49$ & 56 & $0.130-0.134$ \\
\hline G18 & G. 'Sanne' x & 4.07 (M) & 38 & 0.107 & G. sessiliflorum (SE) & & $26,28,52$ & & G. $\times$ oxonianum $(\mathrm{E})$ & $3.22-3.73$ & 26 & $0.124-0.143$ \\
\hline $\mathrm{G} 22$ & G. ‘Tanya Rendall’ w & $3.91(\mathrm{M})$ & 38 & 0.103 & $\begin{array}{c}G . \times \text { antipodeum } \mathrm{y}^{\prime} \\
\text { (SE) }\end{array}$ & - & - & - & G. $\times$ oxonianum $(\mathrm{E})$ & $3.22-3.73$ & 26 & $0.124-0.143$ \\
\hline $\begin{array}{l}\text { G24 } \\
\text { G75 }\end{array}$ & $\begin{array}{l}\text { G. 'Tiny Monster' w' } \\
\text { G. 'Bloomtime' }\end{array}$ & $\begin{array}{l}12.94(\mathrm{P}) \\
6.86(\mathrm{M})\end{array}$ & $\begin{array}{l}108 / 110 \\
26 / 28\end{array}$ & $\begin{array}{l}0.117-0.120 \\
0.245-0.264\end{array}$ & $\begin{array}{l}\text { G. sanguineum (SA) } \\
\text { G. wallichianum (W) }\end{array}$ & $\begin{array}{c}8.78,8.36,8.38 \\
6.78-6.86\end{array}$ & $\begin{aligned} & 84,84 \\
& 28,26,28,56\end{aligned}$ & $\begin{array}{c}0.104 \\
0.242-0.245\end{array}$ & $\begin{array}{l}\text { G. psilostemon (SY) } \\
\text { G. himalayense (PR) }\end{array}$ & $\begin{array}{c}5.18 \\
71-749\end{array}$ & 42 & $\begin{array}{c}0.123 \\
0.130-0.134\end{array}$ \\
\hline G80 & G. 'Blushing Turtle' x & $7.80(\mathrm{M})$ & $\begin{array}{c}20 / 28 \\
66\end{array}$ & $\begin{array}{c}0.245-0.264 \\
0.118\end{array}$ & G. sanguineum (SA) & $\begin{array}{c}\mathbf{0 . 7 8 - 0 . 8 0} \\
8.78,8.36,8.38\end{array}$ & $\begin{array}{c}20, \angle 0, \angle 0,50 \\
84,84\end{array}$ & $\begin{array}{c}0.242-0.245 \\
0.104\end{array}$ & $\begin{array}{l}\text { G. x oxonianum (E) } \\
\text { or G. phhodeloides } \\
\text { (Dissecta) }\end{array}$ & $3.22-3.73$ or - & 26 or $24,26,28$ & $\begin{array}{l}0.124-0.143 \\
\text { or }-\end{array}$ \\
\hline
\end{tabular}


Table 2. Cont.

\begin{tabular}{|c|c|c|c|c|c|c|c|c|c|c|c|c|}
\hline \multicolumn{13}{|c|}{ Subgenus Robertium-Intragroup Crosses } \\
\hline $\begin{array}{l}\text { Genotype } \\
\text { Number }\end{array}$ & Name & $\begin{array}{c}\text { Gen. Size } \\
(\mathrm{pg} / 2 \mathrm{C})\end{array}$ & $\begin{array}{c}\text { Chrom. numb. } \\
(2 \mathrm{n}=)\end{array}$ & DNA/chrom. & Parent 1 & $\begin{array}{c}\text { Gen. Size } \\
(\mathrm{pg} / 2 \mathrm{C})\end{array}$ & $\begin{array}{c}\text { Chrom. numb. } \\
(2 \mathrm{n}=)\end{array}$ & DNA/chrom. & Parent 2 & $\begin{array}{c}\text { Gen. Size } \\
(\mathrm{pg} / 2 \mathrm{C})\end{array}$ & $\begin{array}{c}\text { Chrom. numb. } \\
(2 \mathrm{n}=)\end{array}$ & DNA/chrom \\
\hline $\mathrm{G} 26^{\mathrm{z}}$ & $\begin{array}{l}\text { G. } \times \text { cantabrigiense } \\
\text { 'Berggarten' ww }\end{array}$ & $\left(P g^{\prime}(2)\right.$ & $(211-1)$ & - & $\begin{array}{l}\text { G. maccrorhizum } \\
\text { (MA) }\end{array}$ & 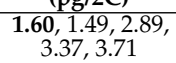 & $46 / 92,46,92$ & - & G. dalmaticum (MA) & $1.56,1.44$ & 46 & 0.033 \\
\hline G27 & $\begin{array}{l}\text { G. } \times \text { cantabrigiense } \\
\text { 'Biokovo' }\end{array}$ & $1.51(\mathrm{M})$ & 46 & 0.033 & $\begin{array}{l}\text { G. maccrorhizum } \\
\text { (MA) }\end{array}$ & $\begin{array}{l}\text { 1.60, } 1.49,2.89 \text {, } \\
3.37,3.71\end{array}$ & $46 / 92,46,92$ & 0.035 & G. dalmaticum (MA) & $1.56,1.44$ & 46 & 0.033 \\
\hline $\mathrm{G} 28^{\mathrm{z}}$ & $\begin{array}{l}\text { G. } \times \text { cantabrigiense } \\
\text { 'Karmina' }\end{array}$ & - & - & - & $\begin{array}{l}\text { G. maccrorhizum } \\
\text { (MA) }\end{array}$ & $\begin{array}{c}\mathbf{1 . 6 0}, 1.49,2.89, \\
3.37,3.71\end{array}$ & $46 / 92,46,92$ & - & G. dalmaticum (MA) & $1.56,1.44$ & 46 & 0.033 \\
\hline $\mathrm{G} 29^{\mathrm{z}}$ & $\begin{array}{c}\text { G. } \times \text { cantabrigiense } \\
\text { 'St Ola' w }\end{array}$ & - & - & - & $\begin{array}{l}\text { G. maccrorhizum } \\
\text { (MA) }\end{array}$ & $\begin{array}{l}\text { 1.60, } 1.49,2.89 \text {, } \\
3.37,3.71\end{array}$ & $46 / 92,46,92$ & - & G. dalmaticum (MA) & $\mathbf{1 . 5 6}, 1.44$ & 46 & 0.033 \\
\hline
\end{tabular}

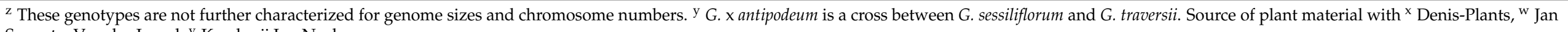
Spruyt-Van der Jeugd, ${ }^{\mathrm{v}}$ Kwekerij Jan Neelen. 


\subsection{Genome Sizes}

Genome sizes were analyzed on young leaf samples on a Quantum P flow cytometer equipped with a laser (488 nm; $180 \mathrm{~mW}$ ) and CyPAD software (Quantum Analysis, Münster, Germany). The CyStain PI kit (Sysmex, Münster, Germany) was used for sample preparation. One piece $\left( \pm 0.5 \mathrm{~cm}^{2}\right)$ of fresh young leaf tissue was chopped using a razor blade [39] together with fresh leaf tissue of the internal standard in $0.4 \mathrm{~mL}$ of extraction buffer. Samples were filtrated through a $50 \mu \mathrm{m}$ CellTrics filter (Sysmex, Münster, Germany) and subsequently $1.2 \mathrm{~mL}$ staining solution (CyStain PI kit) with propidium iodide and RNase A stock solution (both CyStain PI kit) were added. To improve the quality of the histograms, $1.25 \%$ of polyvinylpyrrolidone (PVP10) (Duchefa, Haarlem, The Netherlands) was added to the staining buffer as it is known to bind phenolic compounds [40]. Samples were incubated in the dark at $4{ }^{\circ} \mathrm{C}$ for at least $30 \mathrm{~min}$ before measurement. For each genotype three samples were prepared. These three samples were prepared on different days and, when possible, samples were taken from different plants of the genotype. Each sample analyzed using the flow cytometer histograms obtained with the FL2 and FL3 detector was also analyzed using CyPAD software (Quantum Analysis, Münster, Germany). Genome sizes were calculated from the ratios between peak positions of the Geranium sample and the internal reference with known genome size. Mean values and standard deviations were calculated based on at least six histograms obtained (three samples, two histograms per analysis). Due to the wide range of genome sizes in the genus Geranium, different internal standards were used: Pisum sativum 'Ctirad' 9.09 pg/2C [41], Zea mays 'CE-777' $5.43 \mathrm{pg} / 2 \mathrm{C}$ [42] and Glycine max 'Polanka' $2.50 \mathrm{pg} / 2 \mathrm{C}$ [43]. Terminology on 2C values is used as defined by Greilhuber et al. [44]. A calculated value for the DNA content per chromosome was determined by dividing the genome size through the chromosome number (see below).

\subsection{Chromosome Numbers}

Young root tips were harvested from 2-week-old cuttings of each genotype. The root tips were pre-treated with $0.1 \%$ colchicine $+0.2 \% 500 \times 8$-hydroxyquinoline during $3 \mathrm{~h}$ at $4{ }^{\circ} \mathrm{C}$. Then, the root tips were fixed in 3:1 EtOH:acetic acid for $60 \mathrm{~min}$ at room temperature. Cell suspensions and slide preparation was done according the "SteamDrop" protocol [45]. A $0.6 \%$ enzyme solution ( $0.6 \%$ cellulase, $0.6 \%$ pectolyase, and $0.6 \%$ cytohelicase in $0.1 \mathrm{M}$ citrate buffer ( $0.1 \mathrm{M}$ sodium citrate tribasic dihydrate $+0.1 \mathrm{M}$ citric acid)) was used for incubation at $37^{\circ} \mathrm{C}$ for $40 \mathrm{~min}$. Fixatives used during slide preparation were 2:1 and 1:1 EtOH:acetic acid. Chromosome slides were stained with $1 \%$ DAPI $(100 \mu \mathrm{g} / \mathrm{mL})$ diluted in Vectashield and analyzed using a fluorescence microscope (Axiolmager M2, Carl Zeiss MicroImaging, Belgium) equipped with an Axiocam MRm camera and ZEN software (Carl Zeiss MicroImaging, Belgium) at magnification $1000 \times$. Image analysis was performed in DRAWID v0.26 [46] on at least five well-spread metaphases of each genotype.

\section{Results}

AFLP analysis with four primer pairs generated a total dataset of 872 markers. Based on a PCoA with two factors explaining $17.6 \%$ and $13.8 \%$ of the variation, a division in the subgenera of the Geranium genus is given (Figure 1): Geranium and Erodioidea subgenera are more closely related compared to the subgenus Robertium. Of the five analyzed genotypes in subgenus Robertium, only G44 (G. macrorrhizum 'White Ness') is closer to the Geranium and Erodioidea subgenera.

When specifically focusing on the subgenus Geranium, it can be concluded that the genotypes within a taxonomical group mostly cluster in a two-factorial PCoA explaining $21.9 \%$ and $9.9 \%$ of the variation (Figure 2). The highest genetic distance is found between the Pratense, Platypetalum and Endressii Group, with Platypetalum being the only group in the Tuberosa section. The Endressii Group has one outlier (G19; G. nodosum 'Silverwood'). G71 (G. sylvaticum 'Album') is separated from the other two Sylvaticum Group genotypes (G12 and G62), representing G. psilostemon. This division at species level is also visualized 
in the Pratense Group and Wallichianum Group. For the Pratense Group, three clusters can be recognized: (1) only genotypes of G. pratense (G09, G20, G57, G58, G59 and G60), (2) the 'Brookside' cultivar G04 and G. 'Orion' G14 (which has 'Brookside' as a parent), which are intragroup crosses with G. pratense as one parent, and (3) G38 and G39, which are both cultivars of G. himalayense. In the case for the Wallichianum Group, the intragroup cross G17 (G. 'Salome') is separated from the G. wallichianum species G21 and G76.

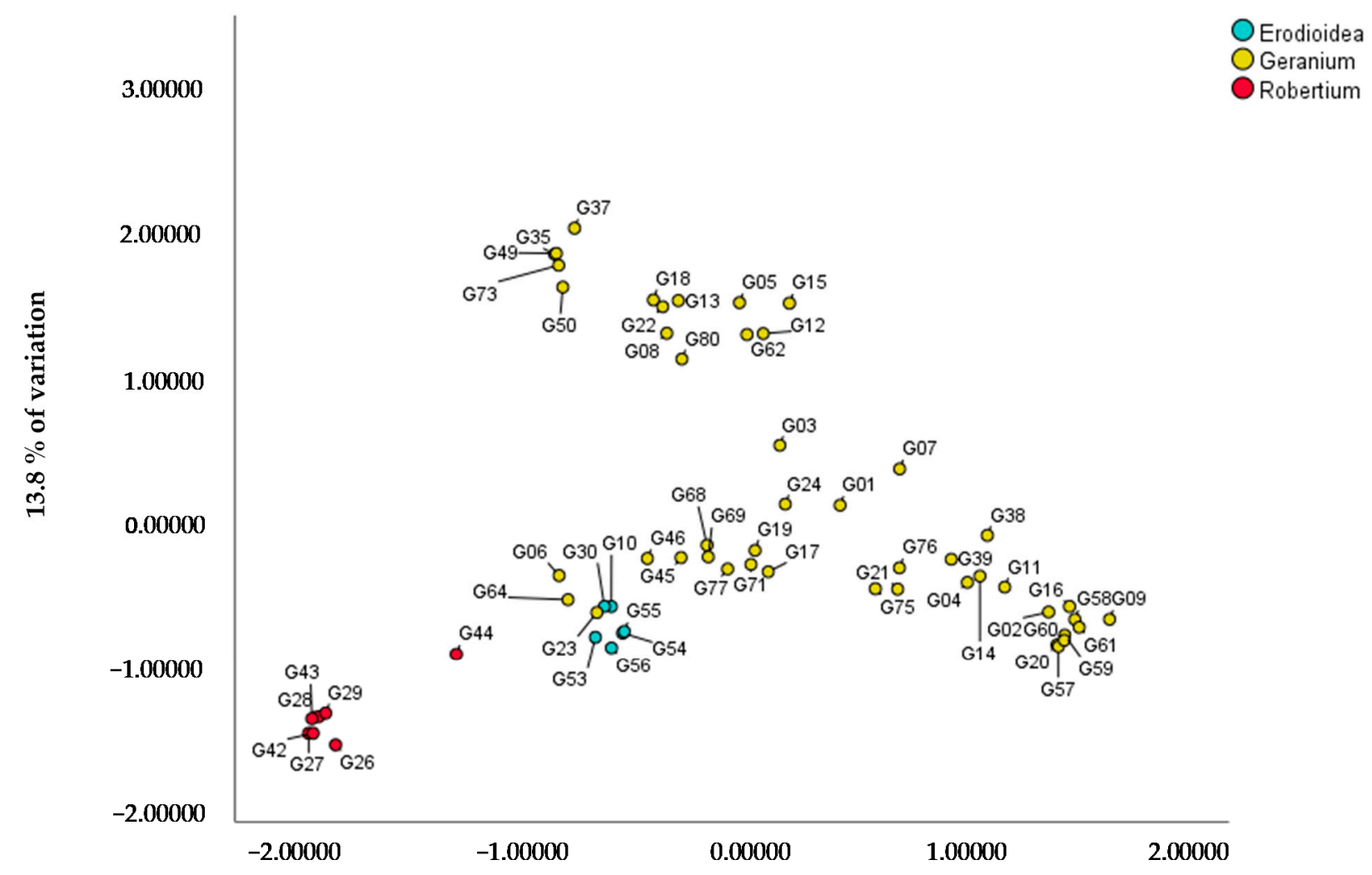

$17.6 \%$ of variation

Figure 1. PCoA based on AFLP data of 61 genotypes of Geranium with the X-and Y-axis comprising $17.6 \%$ and $13.8 \%$ of the variation, respectively.

Almost all intergroup hybrids are clearly located between the six parent groups (Figure 2). For example, most of the intergroup hybrids between the Pratense Group and the Wallichianum Group (G02, G11, G16 and G75) are found in between these two groups, except for $\mathrm{G} 75$ which is located more closely to the Wallichianum-type genotypes. G01 (G. 'Anne Thomson') and G07 (G. 'Dragon Heart') which are progeny of crosses between G. procurrens (Wallichianum Group) and G. psilostemon (Sylvaticum Group) are located in between their parents' groups. The intergroup hybrids between the Endressii Group and the Sessiliflorum Group G08, G13, G18 and G22 are all clustered together. G24 (G. 'Tiny Monster'), progeny of the intergroup combination between G. psilostemon and G. sanguineum, is genetically closer to the included G. sanguineum genotypes (G68 and G69) than to the psilostemon genotypes (G12 and G62) of this collection. G15 (G. 'Patricia'), an intergroup hybrid between the Endressii Group and the Sylvaticum Group (G. psilostemon types), is more closely related to the G. psilostemon types than to the Endressii Group. For G05 (G. 'Catherine Deneuve'), the literature does not agree whether this is a cross product of G. psilostemon and G. × oxonianum or G. psilostemon and G. procurrens. Our PCoA does not indicate close relation to the G. psilostemon $\times$ G. procurrens cross products from our collection (G01 and G07). 


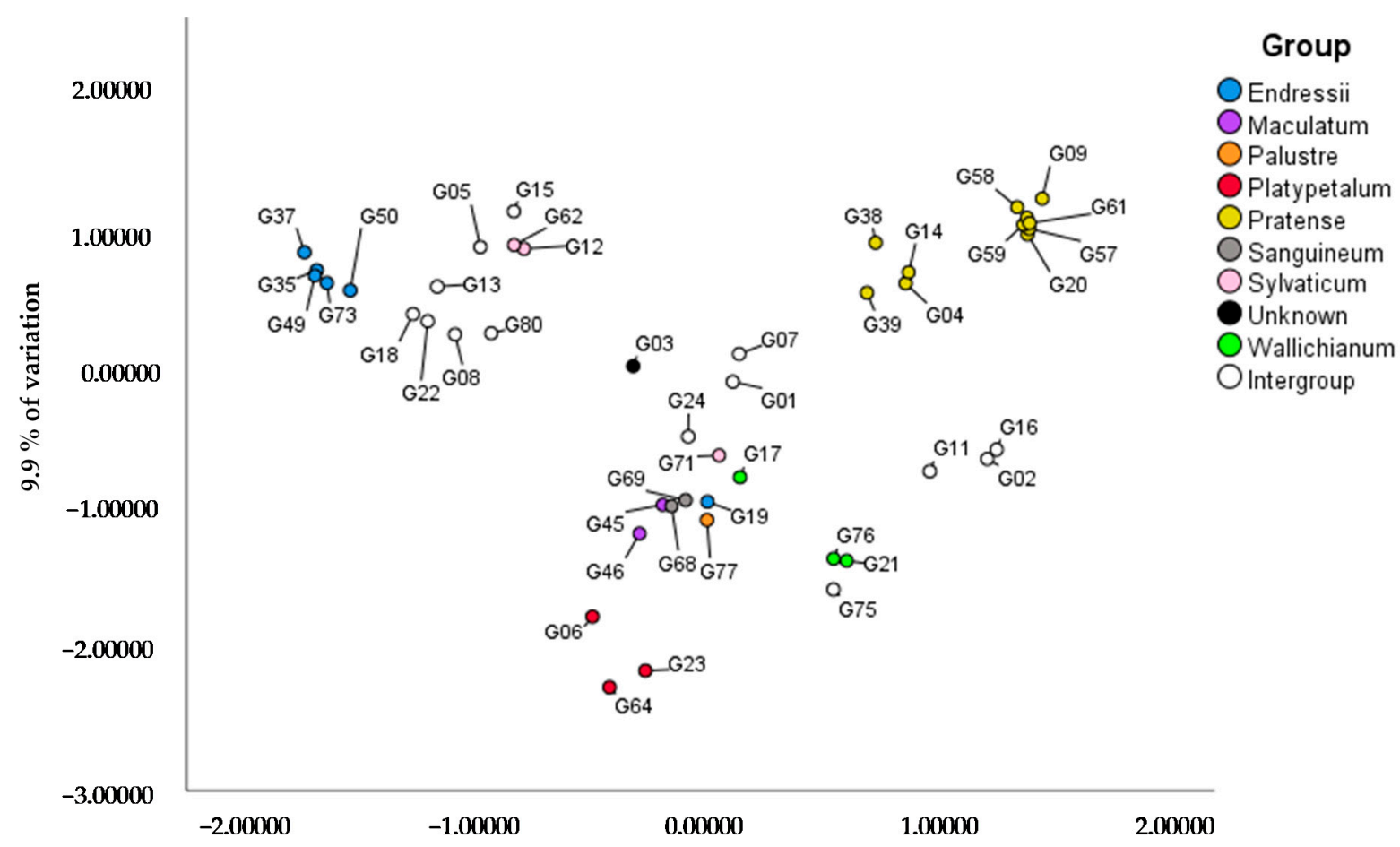

$21.9 \%$ of variation

Figure 2. PCoA based on AFLP data of genotypes of subgenus Geranium (in total 45 plants) with X and Y-axis explaining $21.9 \%$ and $9.9 \%$ of the variation, respectively.

Tables 1 and 2 present the genome sizes, chromosome numbers and DNA content per chromosome of a subgroup of 45 Geranium genotypes. The dendrogram of these genotypes is depicted in supplemental Figure S2. The genome sizes, chromosome numbers and calculated DNA content per chromosome within a taxonomical group and certainly within a species are mostly similar for the subgenera Geranium and Robertium, with only certain intergroup crosses as exception (Tables 1 and 2, Figure S3). However, between groups large differences do occur. For example, the Pratense, Wallichianum, Platypetalum, Cinereum and Phaeum Groups all have 28 chromosomes but a different genome size (Figures S3 and 3).

The Macrorrhizum Group, with analyzed species of G. macrorrhizum G42 (1.60 \pm 0.02 pg/2C), G. $\times$ cantabrigiense G27 (1.51 $\pm 0.01 \mathrm{pg} / 2 \mathrm{C})$ and G. dalmaticum G82 (1.56 \pm 0.06 $\mathrm{pg} / 2 \mathrm{C})$, has the lowest genome sizes with high chromosome numbers $(2 \mathrm{n}=2 \mathrm{x}=46$; G82 not measured). Consequently, the DNA content per chromosome of the Macrorrhizum Group is low, around 0.030 (Tables 1 and 2, Figure S3c). In G44 (G. macrorrhizum 'White Ness'), also belonging to the Macrorrhizum Group of the subgenus Robertium, the genome size $(2.96 \pm 0.06$ $\mathrm{pg} / 2 \mathrm{C})$ and chromosome number $(2 \mathrm{n}=4 \mathrm{x}=92)$ is doubled in comparison to other members of the Macrorrhizum Group, confirming tetraploidy for this genotype (Table 1, Figure S3). In the Pratense Group, the separation that was observed between G. pratense species and G. himalayense species based on PCoA (Figure 2) was confirmed by the presence of two groups with differing genome sizes: one comprised of G14, G38, G39 (6.93 $\pm 0.06,7.31 \pm 0.08,7.49 \pm$ $0.09 \mathrm{pg} / 2 \mathrm{C}$, respectively), and another comprised of G04, G09, G57, G61 and G81 (4.54 \pm $0.0,4.90 \pm 0.03,5.08 \pm 0.04,5.08 \pm 0.02$ and $4.70 \pm 0.07 \mathrm{pg} / 2 \mathrm{C}$, respectively) (Tables 1 and 2, Figures S2 and S3a ). The higher genome size group has a chromosome number of either 42 or 56, while genotypes from the lower genome size group only have 28 chromosomes (Tables 1 and 2, Figure S3b). 


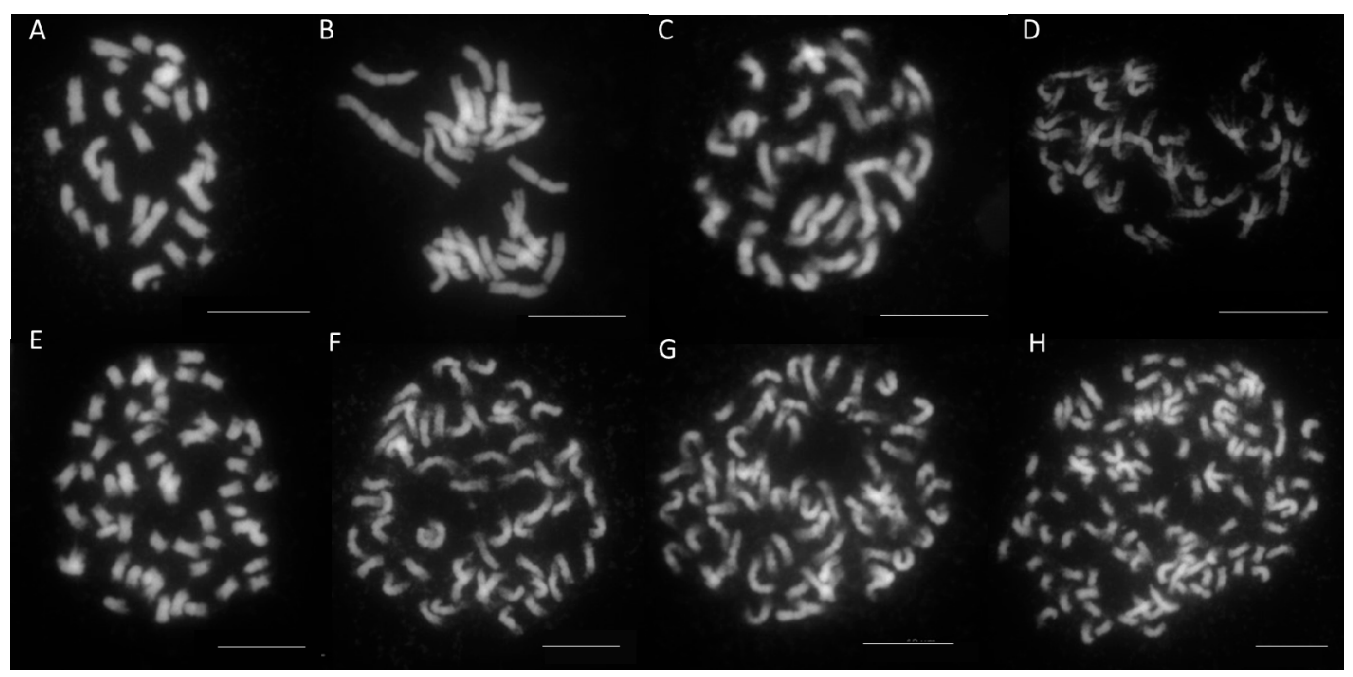

Figure 3. Chromosome counts of Geranium genotypes: (A) G. phaeum 'Angelina' $-3.52 \mathrm{pg} / 2 \mathrm{C}$ and 2n $=28$; (B) G. wallichianum 'Sylvia's surprise' $-6.78 \mathrm{pg} / 2 \mathrm{C}$ and $2 \mathrm{n}=38$; (C) G. $\times$ riversleaianum 'Mavis Simpson' $-4.31 \mathrm{pg} / 2 \mathrm{C}$ and 2n = 38; (D) G. 'Azure Rush'-8.90 pg/2C and 2n = 42; (E) G. 'Catherine Deneuve'-6.95 pg/2C and 2n = 54; (F) G. himalayense 'Derrick Cook' $-7.49 \mathrm{pg} / 2 \mathrm{C}$ and $2 \mathrm{n}=56$; (G) G. sanguineum 'Blushing Turtle' $-7.80 \mathrm{pg} / 2 \mathrm{C}$ and 2n = 66; (H) G. 'Tiny Monster' -12.94 $\mathrm{pg} / 2 \mathrm{C}$ and $2 \mathrm{n}=108 / 110(\mathrm{bar}=10 \mu \mathrm{m})$.

The DNA content per chromosome of the selected collection is mostly between 0.103 and $0.185 \mathrm{pg} / \mathrm{chromosome} \mathrm{except} \mathrm{for} \mathrm{Wallichianum,} \mathrm{Palustre,} \mathrm{Macrorrhizum} \mathrm{and} \mathrm{Cinereum}$ Groups (Tables 1 and 2, Figure S2). For Wallichianum, Palustre and Cinereum this value was higher than $0.200 \mathrm{pg} / \mathrm{chromosome}$. Species in the Wallichianum group and Cinereum group have rather high genome sizes (between 6.06 and $6.86 \mathrm{pg} / 2 \mathrm{C}$ ) and only 28 chromosomes. The highest genome sizes of the collection, excluding intergroup hybrids, were seen in G77 (G. wlassovianum, Palustre Group) and G69 (G. sanguineum 'Album', Sanguineum Group) with $11.50 \pm 0.02$ and $8.78 \pm 0.07$, respectively (Tables 1 and 2, Figure S3a). For G69, this high genome size is linked with a high chromosome number of $2 \mathrm{n}=84$, while G77 has a chromosome number of 56 (Table 1, Figure S3b).

The intra- and intergroup hybrids reveal different scenarios according to chromosome count (Table 2, Figure 3). For the (generally more easily obtained) intragroup hybrids, the chromosome number examined in the hybrids can be predicted by the sum of the gametes of the parental species. This is also the case for the intergroup hybrid G. 'Rozanne' G16. However, for most of the intergroup hybrids an aberrant chromosome number was counted, assuming unreduced gametes could be involved (Table 2, Figure 3). For example, G. 'Catherine Deneuve' G05 with 54 chromosomes could be a result of the unreduced number of $G$. psilostemon and the normal gamete constitution of $G$. × oxonianum, which makes 55 chromosomes. For G. 'Bloomtime' G75, a reduction in chromosome number occurred compared to its parental chromosome constitution.

The genome size of hybrids as compared to their parents (Table 2) were mostly in line with expectations based on parental genome size. Exceptions were the intergroup crosses G05, G16 and G24, as these crosses showed a larger genome size value than expected. For G05 and G24, a possible explanation could be the occurrence of unreduced gametes in one or both parents. The DNA content per chromosome of intra- or intergroup hybrids showed no deviation compared to its parents (Table 2).

In Table 3 the Jaccard similarity coefficients of the parental species and cultivars of described hybrids is shown. Jaccard similarity coefficients in our collection range between 0.091 between G. macrorrhizum and G. pratense (different groups within subgenus Geranium) and 0.506 between G. endressii and G. versicolor (both in Endressii group). The nearest Jaccard similarity coefficients between two subgenera is 0.164 , i.e., between G. cinereum (in Cinereum Group of subgenus Erodioidea) and G. maculatum (in Maculatum Group of subgenus Geranium). An examination of Jaccard similarity coefficients of either existing 
interspecific crosses included in our collection or known cross combinations in the literature reveals that the lowest Jaccard similarity coefficient found in an intergroup hybrid is 0.130 (G. 'Salome' $\times$ G. $\times$ oxonianum). We therefore presume this could be a possible theoretical threshold for cross-compatibility in Geranium.

Table 3. Calculation of the pairwise genetic proximity measures (Jaccard similarity coefficients) of some different Geranium species and cultivars used in obtained cross combinations. When more than one species was available, a mean value was used and designated by *. The numbers depicted in orange are intergroup cross combinations; numbers in blue are intragroup crosses.

\begin{tabular}{|c|c|c|c|c|c|c|c|c|c|c|c|c|c|c|c|c|c|c|c|}
\hline Genotype & 1 & 2 & $3 *$ & $4 *$ & 5 & 6 & 7 & $8 *$ & 9 & $10 *$ & $11 *$ & $12 *$ & $13 *$ & $14 *$ & $15 *$ & 16 & $17 *$ & 18 & 19 \\
\hline 1. G. 'Brookside' & 1.000 & & & & & & & & & & & & & & & & & & \\
\hline 2. G. pratense & 0.298 & 1.000 & & & & & & & & & & & & & & & & & \\
\hline 3. G. cinereum * & 0.132 & 0.120 & 1.000 & & & & & & & & & & & & & & & & \\
\hline 4. G. psilostemon * & 0.201 & 0.178 & 0.163 & 1.000 & & & & & & & & & & & & & & & \\
\hline 5. G. 'Rozanne' & 0.273 & 0.310 & 0.127 & 0.186 & 1.000 & & & & & & & & & & & & & & \\
\hline 6. G. 'Salome' & 0.180 & 0.185 & 0.143 & 0.183 & 0.189 & 1.000 & & & & & & & & & & & & & \\
\hline 7. G. nodosum & 0.209 & 0.173 & 0.146 & 0.181 & 0.185 & 0.165 & 1.000 & & & & & & & & & & & & \\
\hline 8. G. wallichianum * & 0.194 & 0.220 & 0.134 & 0.188 & 0.426 & 0.179 & 0.204 & 1.000 & & & & & & & & & & & \\
\hline 9. G. $\times$ cantabrigiense & 0.136 & 0.091 & 0.098 & 0.115 & 0.105 & 0.131 & 0.101 & 0.105 & 1.000 & & & & & & & & & & \\
\hline 10. G. endressii & 0.146 & 0.155 & 0.133 & 0.292 & 0.147 & 0.151 & 0.173 & 0.136 & 0.151 & 1.000 & & & & & & & & & \\
\hline 11. G. himalayense * & 0.348 & 0.302 & 0.156 & 0.235 & 0.259 & 0.194 & 0.208 & 0.181 & 0.115 & 0.173 & 1.000 & & & & & & & & \\
\hline 12. G. macrorrhizum * & 0.135 & 0.091 & 0.099 & 0.127 & 0.108 & 0.117 & 0.115 & 0.106 & 0.316 & 0.152 & 0.115 & 1.000 & & & & & & & \\
\hline 13. G. maculatum * & 0.150 & 0.159 & 0.164 & 0.162 & 0.143 & 0.162 & 0.125 & 0.127 & 0.113 & 0.166 & 0.173 & 0.106 & 1.000 & & & & & & \\
\hline 14. G. × oxonianum * & 0.153 & 0.141 & 0.124 & 0.244 & 0.143 & 0.130 & 0.152 & 0.143 & 0.128 & 0.593 & 0.161 & 0.148 & 0.147 & 1.000 & & & & & \\
\hline 15. G. phaeum* * & 0.125 & 0.136 & 0.165 & 0.135 & 0.137 & 0.129 & 0.129 & 0.149 & 0.111 & 0.119 & 0.137 & 0.094 & 0.111 & 0.135 & 1.000 & & & & \\
\hline 16. G. renardii & 0.124 & 0.111 & 0.146 & 0.128 & 0.124 & 0.153 & 0.153 & 0.137 & 0.108 & 0.132 & 0.126 & 0.109 & 0.148 & 0.127 & 0.146 & 1.000 & & & \\
\hline 17. G. sanguineum * & 0.193 & 0.169 & 0.132 & 0.167 & 0.178 & 0.171 & 0.194 & 0.160 & 0.146 & 0.150 & 0.198 & 0.144 & 0.144 & 0.139 & 0.147 & 0.144 & 1.000 & & \\
\hline 18. G. sylvaticum & 0.201 & 0.204 & 0.135 & 0.192 & 0.165 & 0.148 & 0.175 & 0.172 & 0.121 & 0.149 & 0.189 & 0.120 & 0.149 & 0.150 & 0.156 & 0.123 & 0.196 & 1.000 & \\
\hline 19. G. versicolor & 0.152 & 0.135 & 0.131 & 0.281 & 0.121 & 0.142 & 0.142 & 0.153 & 0.144 & 0.506 & 0.156 & 0.136 & 0.149 & 0.484 & 0.128 & 0.136 & 0.153 & 0.147 & 1.000 \\
\hline 20. G. wlassovianum & 0.163 & 0.151 & 0.143 & 0.177 & 0.186 & 0.159 & 0.240 & 0.217 & 0.134 & 0.128 & 0.216 & 0.126 & 0.137 & 0.152 & 0.145 & 0.152 & 0.156 & 0.203 & 0.135 \\
\hline
\end{tabular}

\section{Discussion}

The PCoA of all the plants of our collection was in accordance with Yeo [7] who divided the Geranium genus into these three subgenera based on different seed discharge mechanisms [47]. In addition, as also discovered by Marcussen et al. [8], the subgenera Geranium and Erodioidea clustered more closely together compared to Robertium. This was already hypothesized by Bremner, a Geranium breeder who could not achieve any successful cross between species of subgenus Robertium and the two other subgenera [7]. Based on a similar PCoA performed specifically for the Geranium subgenus, the Pratense, Platypetalum and Endressii Groups showed the highest genetic distance in our collection, with the Platypetalum Group being the only one in the Tuberosa section and also clearly isolated from the other groups in the Geranium section [7]. Bremner also noted that no viable seeds were obtained in crosses between Platypetalum and other groups and no offspring is yet described between species of the three most genetically distant groups: Pratense, Platypetalum and Endressii [7]. Our AFLP analysis reveals a possible error in the classification into taxonomic groups by Yeo [7]. In our opinion, G. nodosum (G19) is erroneously classified in the Endressii Group as it is not clustered with other genotypes of the Endressii Group and its closest relative in our collection is G. wlassovianum (G77) in the Palustre Group. This could explain the failure of intragroup crosses using G. nodosum [7]. The chromosome counts found in our study are in accordance with the literature $[14,17,48-55]$. Our results for $G$. wallichianum $\mathrm{G} 21$ and $\mathrm{G} 76(2 \mathrm{n}=2 \mathrm{x}=28)$ were confirmed by Kumar et al. $[49,51]$ although some studies report $2 n=2 x=26$ [56] and $2 n=4 x$ $=56$ [48]. As Yeo reports [17], $2 n=2 x=28$ is most common in Geranium genotypes. Our study reports chromosome numbers for an additional 19 genotypes, mostly commercial cultivars, for which no chromosome data were previously available. This results in 12 chromosome numbers in the section Geranium instead of 11 as reported by Yeo [7]. The genome sizes found in our collection were within the range of those reported in the literature $[15,16,57,58]$. The genome sizes found by Zonneveld [16] for G. endressii (3.13 pg/2C), G. nodosum (3.53 pg/2C), G. phaeum (3.37 pg/2C), G. pratense (4.83 pg/2C), G. sanguineum (8.36 pg/2C) and G. sylvaticum $(4.92 \mathrm{pg} / 2 \mathrm{C})$ were also in the same range as in our study. The only difference between our results and the literature was the genome size of G. macrorrhizum (G42) $(1.60 \mathrm{pg} / 2 \mathrm{C}$ in our study versus $3.71 \mathrm{pg} / 2 \mathrm{C}$ in the literature) [14]. Drawing conclusions on polyploidy is not easy as variation in ploidy levels was seldom found within a species. For G. macrorrhizum 
'White Ness' G44 ( $2 \mathrm{n}=4 \mathrm{x}=92)$ tetraploidy was noticed, as confirmed by Tan [15], while G42, G. macrorrhizum 'Czakor', is assumed to be diploid $(2 n=2 x=46)$. Tetraploids are rare, but for G. maccrorhizum and other members of section Ruberta, polyploidy and amphidiploidy are clearly evident [17]. Our observations on genome size and ploidy level of G. macrorrhizum were confirmed by Kato et al. [58] who also reported a hexaploid population in the Croatia population $(2 \mathrm{n}=6 \mathrm{x}=3.77 \mathrm{pg} / 2 \mathrm{C})$.

When analyzing the intergroup hybrids, our AFLP analysis, together with the results from chromosome counts and genome size measurements, was able to show their genetic background. A hypothesis is that the DNA content per chromosome in a hybrid seems to resemble the relatedness of the hybrid to its parent; when this value was more similar to one of the parents, this genotype also appeared to be more closely related to this parent in the AFLP. This indicates that the calculated DNA content per chromosome in Geranium can be valuable for predicting genetic relatedness without an AFLP analysis. For example, the successful hybrid cultivar 'Rozanne' (G16), together with the other crossing products of G. wallichianum and G. himalayense (G02, G11 and G75) are more closely related to the G. wallichianum parent. G. 'Rozanne' (G16) and G. 'Azure Rush' (G02) have 42 chromosomes, while G. 'Bloomtime' (G75) has $2 \mathrm{n}=2 \mathrm{x}=28$. However, all three hybrids have a similar DNA content per chromosome of about 0.22 to $0.26 \mathrm{pg} /$ chromosome, comparable to the $G$. wallichianum parent. For G. 'Orion' (G14), the presence of 42 chromosomes clearly reveals its background of a cross between G. 'Brookside' with 28 chromosomes and G. himalayense with 56 chromosomes, although its DNA content per chromosome is more similar to the 'Brookside' parent. Observations for G. 'Blushing Turtle' (G80) showed a clustering near its one parent G. sanguineum, but its chromosome number showed its intergroup character with an aberrant chromosome number of $2 n=66$. G. 'Blushing Turtle' is a crossing product between G. sanguineum with 84 chromosomes [16] and G. × oxonianum (with 26 chromosomes in our collection) or G. asphodeloides (US Plant Patent 22376). G. asphodeloides has 24 chromosomes [2,23]. By calculating all scenarios based on the chromosomal characteristics of the parents, a possible hypothesis is that G. 'Blushing Turtle' contains all the chromosomes of $G$. asphodeloides as well as the haploid level of G. sanguineum, resulting in 66 chromosomes. The origin of G. 'Bob's Blunder' (G03) remains unknown. In our AFLP analysis G03 has the highest relatedness with the intergroup hybrids between the Endressii Group and the Sessiliflorum Group (e.g., G18). Additionally, these hybrids are characterized by brown-colored leaves, which is also the case for 'Bob's Blunder'. Furthermore, it has a similar chromosome number of $2 \mathrm{n}=38$. Our AFLP was also able to uncover a possible parent for genotype G05, G. 'Catherine Deneuve', whose parentage was in doubt. There are two hypotheses about the parentage of G05; US Plant Patent license 223370 [59] described that parents are G. psilostemon and G. procurrens, while later the breeder expressed the belief that it was a hybrid between G. psilostemon and G. × oxonianum. In the dendrogram of our study, G05 is more closely related to to G. 'Patricia' (G15), a hybrid between G. endressii and G. psilostemon. As G. endressii is one of the parents of $G$. $\times$ oxonianum, we presume the breeders' opinion is correct. The chromosome number of G05 $(2 n=54)$ could not be explained by the normal chromosome contribution of the parents $(G . \times$ oxonianum 26 chromosomes and G. psilostemon 42 chromosomes); however, when the unreduced chromosome complement of G. psilostemon is combined with the reduced number of $G$. $\times$ oxonianum (13), the sum is almost correct. G. 'Tiny Monster' (G24) showed the highest chromosome number $(2 \mathrm{n}=$ 108-110). Presuming the absence of unreduced gametes, this is difficult to explain based on the chromosome number of the parents ( $G$. sanguineum $2 \mathrm{n}=84$ and G. psilostemon $2 \mathrm{n}=42$ ). Additionally, the intergroup hybrids of Endressii and Sessiliflorum Group, like G. 'Sanne' (G18), G. 'Tanya Rendall' (G22) and G. $\times$ riversleaianum 'Mavis Simpson' (G13) which are crosses between (1) G. sessiliflorum $(2 \mathrm{n}=52)$ [56] and $G$. $\times$ oxonianum $(2 \mathrm{n}=2 \mathrm{x}=26$, this study), (2) G. × antipodeum (no chromosome data but cross between $G$. sessiliflorum and G. traversii) and $G$. $\times$ oxonianum $(2 n=2 x=26$, this study) and ( 3$)$ G. endressii $(2 n=2 x=26$ or 28 , this study) and G. traversii $(2 n=2 x=52-54)[56,60]$, respectively, all show a similar chromosome number of $2 \mathrm{n}=2 \mathrm{x}=38$, which is clearly the result of hybridization. This study 
showed that chromosome numbers, genome sizes, genetic relatedness and DNA content per chromosome could provide additional information about genotypes with unknown or unclear parentage. The examination of hybrids in this study also revealed that similar chromosome number is not a prerequisite for successful cross combinations, although these successful hybrids often result in aberrant chromosome numbers. An aberrant chromosome number is often found in interspecific crosses and occurs more in genetically distant cross combinations [61]. A high level of variance in parental genome sizes and DNA content per chromosome was not observed in many intra- and intergroup hybrids included in this study, indicating that similarity of genome size and DNA content could be a requirement for successful hybridization. G. nodosum cannot be crossed with G. endressii despite similar chromosome numbers, similar genome size and similar DNA content per chromosome. Their pairwise proximity coefficient is 0.173 , which presumably indicates the importance of the genetic distance in successful mating, as we have observed in Geranium. This study has shown that the presumed lower limit of 0.130 of pairwise Jaccard similarity coefficient of the parents can be taken as a threshold to successful intergroup crosses in the Geranium genus (without taking all other breeding barriers into consideration), with the value around 0.5 indicating easier (intragroup) crossings. An examination of the pairwise genetic proximity of the species of Robertium (G. $\times$ cantabrigiense and G. macrorrhizum) in comparison with the species of the other subgenera in this collection revealed many values below this 0.130 limit. The maximum Jaccard similarity coefficient between them was 0.151 (between G. $\times$ cantabrigiense and G. endressii) and the minimum was 0.091 (between G. pratense and G. macrorrhizum or G. $\times$ cantabrigiense). This could explain the inability of Robertium species to cross with other subgenera. In addition, the DNA content per chromosome (approximately 0.03) in the subgenus Robertium was clearly atypical in comparison to all other genotypes, which raises the hypothesis that also this could affect success of hybridization with other subgenera and species.

\section{Conclusions}

We can conclude that knowledge about the genetic distance, genome size or chromosome number can support breeding efforts in Geranium. The DNA content per chromosome can be used as an alternative method to calculate the relatedness of the hybrid with its parents. Clearly, genetic relatedness is very important for cross compatibility in Geranium. We showed that easy cross combinations mostly have a pairwise proximity distance of around 0.5 , with a minimum value of 0.130 required for hybridization. Although other fertilization barriers can probably also limit crossing success, we hypothesize that the pairwise Jaccard similarity coefficients can be a possible first determinator for successful cross hybridization in Geranium. An analysis of crossing products showed that an equal number of chromosomes is not a prerequisite to result in successful offspring and chromosome numbers are often aberrant in intergroup hybrids. As regards there being no odd chromosome numbers in Geranium, perhaps abnormal gametogenesis, like unreduced gamete production, in Geranium is common which should be evaluated in a future study. Genome sizes vary widely in Geranium, but successful crosses often show a more narrow variation in genome size between the parents.

When working with as-yet unknown genotypes, breeders can use our data and measurements of genome size and chromosome numbers to gain information about the plants' backgrounds and predict the success of potential crossings. This will support the success of future breeding programs.

Supplementary Materials: The following are available online at https:/ / www.mdpi.com/article/10 .3390/genes12050730/s1, Figure S1: Classification of Geranium genus according to the Yeo, Figure S2: Phylogenetic tree of 45 Geranium genotypes with their genome sizes (pg/2C), chromosome numbers (Chrom. numb. (2n)) and calculated DNA content per chromosome (DNA/chromo. (pg/chromosome)), Figure S3: (a) Genome sizes (pg/2C), (b) chromosome numbers (2n) and (c) calculated DNA content per chromosome (pg/chromosome) of different genotypes of Geranium divided into taxonomic groups according to Yeo. 
Author Contributions: Conceptualization, M.A. and E.D.; methodology, M.A., K.V.L., L.L., J.D.R. and E.D.; data curation, M.A.; writing—original draft preparation, M.A.; writing-review and editing, M.A., K.V.L., L.L., J.D.R., J.V.H., S.P.O.W. and E.D.; visualization, M.A.; supervision, E.D., J.V.H. and S.P.O.W. All authors have read and agreed to the published version of the manuscript.

Funding: This research received no external funding.

Institutional Review Board Statement: Not applicable.

Informed Consent Statement: Not applicable.

Data Availability Statement: The data presented in this study are available on request from the corresponding author. The data are not publicly available because this research was in collaboration with a private company.

Acknowledgments: The authors would like to sincerely thank Dirk Gunst for justifying our collection. Special thanks to Veerle Buysens for AFLP, Magali Losschaert for DNA extraction and chromosome counting, Michiel Caron and Nancy Mergan for genome size measurements. We would also like to thank Roger Dobbelaere and Rina Vanhaecke for their excellent management of the greenhouse plants. Thanks also go to Miriam Levenson for English-language editing.

Conflicts of Interest: The authors declare no conflict of interest.

\section{References}

1. Aedo, C. Taxonomic revision of Geranium sections batrachioidea and divaricata (Geraniaceae). Ann. Missouri Bot. Gard. 1998, 85, 594-630. [CrossRef]

2. Aedo, C.; Fiz, O.; Alarcón, M.L.; Navarro, C.; Aldasoro, J.J. Taxonomic revision of Geranium sect. Dissecta (Geraniaceae). Syst. Bot. 2005, 30, 533-558. [CrossRef]

3. Albers, F.; Van der Walt, J.J.A. Geraniaceae. In Flowering Plants·Eudicots, 1st ed.; Kubitzki, K., Ed.; Springer: Berlin/Heidelberg, Germany, 2007; Volume 5, pp. 157-167.

4. Price, R.A.; Palmer, J.D. Phylogenetic Relationships of the Geraniaceae and Geraniales from rbcL Sequence Comparisons. Ann. Missouri Bot. Gard. 1993, 80, 661-671. [CrossRef]

5. Aedo, C. Taxonomic revision of Geranium sect. Brasiliensia (Geraniaceae). Syst. Bot. 2001, 26, 205-215. [CrossRef]

6. Mitchell, A.D.; Heenan, P.B.; Paterson, A.M. Phylogenetic relationships of Geranium species indigenous to New Zealand. N. Z. J. Bot. 2009, 47, 21-31. [CrossRef]

7. Yeo, P.F. Hardy Geraniums, 2rd ed.; Timber Press, Inc.: Portland, OR, USA, 2001; ISBN 0713485000.

8. Marcussen, T.; Meseguer, A.S. Species-level phylogeny, fruit evolution and diversification history of Geranium (Geraniaceae). Mol. Phylogenet. Evol. 2017, 110, 134-149. [CrossRef]

9. Armitage, J. RHS Plant Trials and Awards Hardy Geraniums-Stage 3 and Geraniums Suitable for Rock Gardens Stage 3 of the Trial of Hardy Geraniums and Geraniums Suitable for Rock Gardens. RHS 2007, 17, 1-16.

10. Veselý, P.; Bureš, P.; Šmarda, P. Nutrient reserves may allow for genome size increase: Evidence from comparison of geophytes and their sister non-geophytic relatives. Ann. Bot. 2013, 112, 1193-1200. [CrossRef] [PubMed]

11. Veselý, P.; Bureš, P.; Šmarda, P.; Pavlíček, T. Genome size and DNA base composition of geophytes: The mirror of phenology and ecology? Ann. Bot. 2012, 109, 65-75. [CrossRef] [PubMed]

12. Bureš, P.; Wang, Y.F.; Horová, L.; Suda, J. Genome size variation in Central European species of Cirsium (Compositae) and their natural hybrids. Ann. Bot. 2004, 94, 353-363. [CrossRef]

13. Dewitte, A.; Leus, L.; Eeckhaut, T.; Vanstechelman, I.; van Huylenbroeck, J.; van Bockstaele, E. Genome size variation in Begonia. Genome 2009, 52, 829-838. [CrossRef]

14. Siljak-Yakovlev, S.; Pustahija, F.; Šolić, E.M.; Bogunić, F.; Muratović, E.; Bašić, N.; Catrice, O.; Brown, S.C. Towards a genome size and chromosome number database of balkan flora: C-values in 343 taxa with novel values for 242. Adv. Sci. Lett. 2010, 3, 190-213. [CrossRef]

15. Tan, K.; Siljak-Yakovlev, S.; Vold, G. Geranium kikianum sp. nov. (Geraniaceae) from the southern Peloponnese, Greece. Nord. J. Bot. 2011, 29, 1-5. [CrossRef]

16. Zonneveld, B.J.M. The DNA weights per nucleus (genome size) of more than 2350 species of the Flora of The Netherlands, of which 1370 are new to science, including the pattern of their DNA peaks. Forum Geobot. 2019, 8, 24-78. [CrossRef]

17. Yeo, P.F. The morphology and affinities of Geranium sections Lucida and Unguiculata. Bot. J. Linn. Soc. 2004, 144, 409-429. [CrossRef]

18. Khan, N.A.; Singhal, V.K.; Tantray, Y.R.; Kumar, R.; Gupta, R.C. A case of intraspecific euploidy $(2 \times, 4 \times)$ and secondary chromosomal associations in wild accessions of Geranium pratense L. from cold deserts of Ladakh (India). Nucleus 2020, 63, 143-149. [CrossRef]

19. Aedo, C. The genus geranium L. (geraniaceae) in North America. I. Annual species. An. Jardín Botánico Madr. 2000, 58, 39-82. [CrossRef] 
20. Pax, D.L.; Price, R.A.; Michaels, H.J. Phylogenetic position of the Hawaiian geraniums based on rbc L Sequences. Am. J. Bot. 1997, 84, 72-78. [CrossRef]

21. Koloren, O.; Eker, S. Phylogenetic relationships of geranium species in different regions of Turkey. Fresenius Environ. Bull. 2016, $25,5467-5472$.

22. Fiz, O.; Vargas, P.; Alarcón, M.; Aedo, C.; García, J.L.; Aldasoro, J.J. Phylogeny and historical biogeography of geraniaceae in relation to climate changes and pollination ecology. Syst. Bot. 2008, 33, 326-342. [CrossRef]

23. Van Huylenbroeck, J.; Eeckhaut, T.; Leus, L.; van Laere, K.; Dhooghe, E. Bridging the gap: Tools for interspecific and intergeneric hybridization in ornamentals. Acta Hortic. 2020, 1283, 161-168. [CrossRef]

24. Kubota, S.; Konno, I.; Kanno, A. Molecular phylogeny of the genus Asparagus (Asparagaceae) explains interspecific crossability between the garden asparagus (A. officinalis) and other Asparagus species. Theor. Appl. Genet. 2012. [CrossRef] [PubMed]

25. Watanabe, H.; Ando, T.; Iida, S.; Suzuki, A.; Buto, K.; Tsukamoto, T.; Hashimoto, G.; Marchesi, E. Cross compatibility of Petunia cultivars and P. axillaris with native taxa of Petunia in relation to their chromosome number. J. Jpn. Soc. Hortic. Sci. 1996, 65, 625-634. [CrossRef]

26. Van Laere, K.; Leus, L.; Van Huylenbroeck, J.; Van Bockstaele, E. Interspecific hybridisation and genome size analysis in Buddleja. Euphytica 2009, 166, 445-456. [CrossRef]

27. Denaeghel, H.; Laere, K.V.; Leus, L.; Huylenbroeck, J.V. Interspecific hybridization in Sarcococca supported by analysis of ploidy level, genome size and genetic relationships. Euphytica 2017, 213, 149. [CrossRef]

28. Dhooghe, E.; Sparke, J.; Oenings, P.; Van Paemel, T.; Van Labeke, M.-C.; Winkelmann, T. Helleborus. In Ornamental Crops; Van Huylenbroeck, J., Ed.; Springer International Publishing: Cham, Switzerland, 2018; pp. 439-452. ISBN 978-3-319-90698-0.

29. Kardos, J.H.; Robacker, C.D.; Dirr, M.A.; Rinehart, T.A. Production and Verification of Hydrangea macrophylla $\times$ H. angustipetala Hybrids. HortScience 2009, 44, 1534-1537. [CrossRef]

30. Kudo, N.; Niimi, Y. Production of interspecific hybrid plants through cotyledonary segment culture of embryos derived from crosses between Hydrangea macrophylla f. hortensia (Lam.) Rehd. and H. arborescens L. J. Jpn. Soc. Hortic. Sci. 1999, 68, 803-809. [CrossRef]

31. Reed, S.M.; Riedel, G.L.; Pooler, M.R. Verification and Establishment of Hydrangea macrophylla 'Kardinal' $\times$ H. paniculata 'Brussels Lace' Interspecific Hybrids. J. Environ. Hortic. 2001, 19, 85-88. [CrossRef]

32. Samain, M.S.; Wanke, S.; Goetghebeur, P. Unraveling extensive paraphyly in the genus Hydrangea s. l. with implications for the systematics of tribe Hydrangeeae. Syst. Bot. 2010, 35, 593-600. [CrossRef]

33. Reed, S.M.; Jones, K.D.; Rinehart, T.A. Production and characterization of intergeneric hybrids between Dichroa febrifuga and Hydrangea macrophylla. J. Am. Soc. Hortic. Sci. 2008, 133, 84-91. [CrossRef]

34. Van Laere, K.; Hermans, D.; Leus, L.; Van Huylenbroeck, J. Genetic relationships in European and Asiatic Buxus species based on AFLP markers, genome sizes and chromosome numbers. Plant Syst. Evol. 2011, 293, 1-11. [CrossRef]

35. Doyle, J. DNA protocols for plants. In Molecular Techniques in Taxonomy; Springer: Berlin/Heidelberg, Germany, 1991; Volume 57, pp. 283-293. [CrossRef]

36. Vos, P.; Hogers, R.; Bleeker, M.; Reijans, M.; Van De Lee, T.; Hornes, M.; Friters, A.; Pot, J.; Paleman, J.; Kuiper, M.; et al. AFLP: A new technique for DNA fingerprinting. Nucleic Acids Res. 1995, 23, 4407-4414. [CrossRef] [PubMed]

37. De Riek, J.; Dendauw, J.; Mertens, M.; De Loose, M.; Heursel, J.; Van Blockstaele, E. Validation of criteria for the selection of AFLP markers to assess the genetic variation of a breeders' collection of evergreen azaleas. Theor. Appl. Genet. 1999, 99, 1155-1165. [CrossRef]

38. Elmer, P. AFLP Plant Mapping Kit Protocol (P/N 402083); Perkin Elmer: Foster City, CA, USA, 1995.

39. Galbraith, D.W.; Harkins, K.R.; Maddox, J.M.; Ayres, N.M.; Sharma, D.P.; Firoozabady, E. Rapid flow cytometric analysis of the cell cycle in intact plant tissues. Science 1983, 220, 1049-1051. [CrossRef]

40. Doležel, J.; Bartoš, J.A.N. Plant DNA flow cytometry and estimation of nuclear genome size. Ann. Bot. 2005, 95, 99-110. [CrossRef]

41. Doležel, J.; Sgorbati, S.; Lucretti, S. Comparison of three DNA fluorochromes for flow cytometric estimation of nuclear DNA content in plants. Physiol. Plant. 1992. [CrossRef]

42. Lysak, M.A.; Dolezel, J. Estimation of nuclear DNA content in Sesleria (Poaceae). Caryologia 1998. [CrossRef]

43. Doležel, J.; Doleželová, M.; Novák, F.J. Flow cytometric estimation of nuclear DNA amount in diploid bananas (Musa acuminata and M. balbisiana). Biol. Plant. 1994. [CrossRef]

44. Greilhuber, J.; Doležel, J.; Lysák, M.A.; Bennett, M.D. The origin, evolution and proposed stabilization of the terms "genome size" and "C-value" to describe nuclear DNA contents. Ann. Bot. 2005, 95, 255-260. [CrossRef]

45. Kirov, I.; Divashuk, M.; Van Laere, K.; Soloviev, A.; Khrustaleva, L. An easy "steamDrop" method for high quality plant chromosome preparation. Mol. Cytogenet. 2014. [CrossRef]

46. Kirov, I.; Khrustaleva, L.; Van Laere, K.; Soloviev, A.; Meeus, S.; Romanov, D.; Fesenko, I. DRAWID: User-friendly java software for chromosome measurements and idiogram drawing. Comp. Cytogenet. 2017. [CrossRef] [PubMed]

47. Yeo, P.F. Fruit-discharge-type in Geranium (Geraniaceae): Its use in classification and its evolutionary implications. Bot. J. Linn. Soc. 1984, 89, 1-36. [CrossRef]

48. Rani, S.; Kumari, S.; Gupta, R.C.; Chahota, R.K. Cytological studies of Angiosperms (174 species) from District Kangra, Himachal Pradesh (India). Plant Syst. Evol. 2013, 300, 851-862. [CrossRef] 
49. Singhal, V.K.; Singh, J.; Kaur, S.; Kumar, R. Chromosome counts through male meiosis in some dicots from the Hills around Shimla, Himachal Pradesh. Cytologia (Tokyo) 2016, 81, 183-188. [CrossRef]

50. Kumar, P.; Singhal, V.K. Ethnobotany and Ethnomedicinal Uses, Chromosomal Status and Natural Propagation of Some Plants of Lahaul-Spiti and Adjoining Hills. J. Bot. 2013, 2013, 1-14. [CrossRef]

51. Kumar, P.; Kumar, V. Chromosome number, male meiosis and pollen fertility in selected angiosperms of the cold deserts of Lahaul-Spiti and adjoining areas ( Himachal Pradesh, India ). Plant Syst. Evol. 2011, 297, 271-297. [CrossRef]

52. Kumar, P.; Singhal, V.K.; Singh, H. Intraspecific floral morphotypes in six high altitude perennial herbaceous species from northwest Himalaya: Their chromosome counts, meiotic behavior and pollen fertility. Nucleus 2018, 61, 35-43. [CrossRef]

53. Kuzmanov, B. Chromosome numbers of bulgarian angiosperms: An introduction to a chromosome atlas of the Bulgarian flora. Flora Mediterr. 1993, 3, 19-163.

54. De Lange, P.J.; Murray, B.G.; Datson, P.M. Contributions to a chromosome atlas of the New Zealand flora-38. Counts for 50 families. N. Z. J. Bot. 2004, 42, 873-904. [CrossRef]

55. Baltisberger, M.; Widmer, A. Karyological data of some angiosperms from Romania. Willdenowia 2009, 39, 353-363. [CrossRef]

56. Roy, S.C. A cytological survey of eastern Himalayan plants. II. Cell Chromosom. Res. 1988, 11, $93-97$.

57. Pustahija, F.; Brown, S.C.; Bogunić, F.; Bašić, N.; Muratović, E.; Ollier, S.; Hidalgo, O.; Bourge, M.; Stevanović, V.; Siljak-Yakovlev, S. Small genomes dominate in plants growing on serpentine soils in West Balkans, an exhaustive study of 8 habitats covering 308 taxa. Plant Soil 2013, 373, 427-453. [CrossRef]

58. Zeljković, S.Ć.; Siljak, S.; Kit, Y.; Milka, T. Chemical composition and antioxidant activity of Geranium macrorrhizum in relation to ploidy level and environmental conditions. Plant Syst. Evol. 2020, 306, 1-12. [CrossRef]

59. Freeman, L.; Diener, J.; Points, F.; Ranch, R.R.; Points, F. United States Plant Patent. U.S. Patent US PP23,370 P2, 22 August 2011.

60. Dawson, M.I. Index of chromosome numbers of indigenous New Zealand spermatophytes. N. Z. J. Bot. 2000, 38, 47-150. [CrossRef]

61. Van Tuyl, J.M.; Lim, K.B. Interspecific hybridisation and polyploidisation as tools in ornamental plant breeding. Acta Hortic. 2003, 612, 13-22. [CrossRef] 